\title{
Soft Skills and ICT Tools for Final Qualification Assessment in Universities of Ukraine and India in COVID-19 Framework
}

\author{
Rusudan Makhachashvili $^{1 *}$, Ivan Semenist ${ }^{2}$, Yuliya Shtaltovna ${ }^{3}$, Anna Bakhtina ${ }^{4}$ \\ ${ }^{1,2,4}$ Borys Grinchenko Kyiv University, Kyiv, Ukraine \\ ${ }^{3}$ XU Exponential University of Applied Sciences, Berlin, Germany \\ *r.makhachashvili@kubg.edu.ua
}

\begin{abstract}
The global pandemic and subsequent quarantine measures and restrictions have posed an array of challenges to the structure and procedure of university summative assessment process. Qualification assessment for Foreign Languages major programs is a strict regimen that involves different stages (oral and written exams, final project viva, internal and external review). This study presents a comprehensive analysis of the practices of Borys Grinchenko Kyiv University (Kyiv, Ukraine) and International Business School (Hyderabad, India) digital qualification assessment for students of European (French, Italian, Spanish, English, German) and Asian (Mandarin, Japanese) Languages major programs, employed in the year 2020 due to quarantine measures. The survey and analysis of different ICT tools is used to translate real life qualification assessment practices into online blended format. The investigation identifies various groups of applied digital skills and soft skills, utilized through qualification assessment process by primary subjects (students). The choice of the considered cases of university Final Qualification Assessment for Foreign Languages major programs is informed by the need to estimate similar and divergent socio-cultural parameters of digital literacy development and application in multi-cultural context. Comparison is provided for integral and differential parameters of Final Qualification Assessment in the universities of Ukraine and India under survey.
\end{abstract}

Keywords

ICT Tools; linguistic education; Final Qualification Assessment; digital literacy; blended learning

\section{Introduction}

The global pandemic and subsequent quarantine measures and restrictions have posed an array of challenges to the structure and procedure of university summative assessment process. Qualification assessment for Foreign Languages major programs in particular is a strict regimen that involves different stages, requiring interoperability of soft and hard skills (oral and written exams, final project viva, internal and external review).

This study objective is to critically review the educational and communicative of framework Digital Final Qualification Assessment at Borys Grinchenko Kyiv University (Kyiv, Ukraine) and International Business School (Hyderabad, India) for students of European (French, Italian, Spanish, English, German) and Oriental (Mandarin Chinese, Japanese) Languages major programs, employed in the year 2020 due to quarantine measures. The survey and analysis of different ICT tools and necessary applied skills is used to assess the translation of real life qualification assessment practices into online blended format.

The investigation also seeks to identify various groups of applied digital skills and collaboration skills, utilized through qualification assessment process by primary subjects (students) in Eastern Europe and Asia. The choice of the considered cases of university Final Qualification Assessment for Foreign Languages major programs is informed by the need to estimate similar and divergent socio-cultural parameters of digital literacy development and application in multicultural context.

The global pandemic of COVID-19 can be considered a black swan scenario for various spheres of social and economic life, including education. The black swan theory is a metaphor to describe an event that comes as a surprise, has a major effect on society, and is often inappropriately rationalized after the fact with the benefit of hindsight (Taleb, 2010).

In the educational sphere, according to the study estimations, the result of the COVID-19 pandemic development was the need to take quick action worldwide in order to achieve such desirable results:

a) To adapt the existent educational scenarios to digital, remote and blended formats; 
b) To boost ICT competence and digital literacy of all participants of the educational process.

\section{Literature Review}

The study elaboration premise included identification of ICT competency principles, derivative of $21^{\text {st }}$ century skills (Abbot 2013; Davies 2011; Dos Reis 2017; Morze, Makhachashvili, Smyrnova-Trybulska 2016; WEF 2020) for educational purposes and respectively projected digital literacy requirements across various comprehensive frameworks:

1) UNESCO Framework (UNESCO 2018) emphasizes that it is not enough for educators to have ICT competencies and be able to teach them to their students. Educators need to be able to help the students become collaborative, problem solving, creative learners through using ICT so they will be effective citizens and members of the workforce. The Framework therefore addresses such aspects of education: Understanding ICT in education, Curriculum and assessment, Pedagogy, ICT, Organization and administration, Teacher professional learning.

2) Liberal Arts (Digital Humanities) ICT proficiency profile sampling elaboration, according to the European e-competence framework guideline (Ecompetences 2020) was conducted. ICT Liberal Arts/Digital Humanities sample profile includes the following components: - Trains ICT professionals and practitioners to reach predefined standards of ICT technical /business competence.

- Provides the knowledge and skills required to ensure that students are able to effectively perform tasks in the workplace.

- Defines and implements ICT training policy to address organizational skill needs and gaps. Structures, organizes and schedules training programs and evaluates training quality through a feedback process and implements continuous improvement. Adapts training plans to address changing demand.

- Organizes the identification of training needs; collates organization requirements, identifies, selects and prepares schedule of training interventions.
- Acts creatively to analyze skills gaps; elaborates specific requirements and identifies potential sources for training provision. Has specialist knowledge of the training market and establishes a feedback mechanism to assess the added value of alternative training programs.

- Monitors and addressees the development needs of individuals and teams.

3) Digital Competence 2020 framework (DigComp 2020), consistent of 5 core parameters assessed according to 16 levels of proficiency:

- Information and data literacy: To articulate information needs, to locate and retrieve digital data, information and content. To judge the relevance of the source and its content. To store, manage, and organize digital data, information and content.

- Communication and collaboration: To interact, communicate and collaborate through digital technologies while being aware of cultural and generational diversity. To participate in society through public and private digital services and participatory citizenship. To manage one's digital identity and reputation.

- Digital content creation: To create and edit digital content. To improve and integrate information and content into an existing body of knowledge while understanding how copyright and licenses are to be applied. To know how to give understandable instructions for a computer system.

- Safety: To protect devices, content, personal data and privacy in digital environments. To protect physical and psychological health, and to be aware of digital technologies for social well-being and social inclusion. To be aware of the environmental impact of digital technologies and their use.

Problem solving: To identify needs and problems, and to resolve conceptual problems and problem situations in digital environments. To use digital tools to innovate processes and products. To keep up-to-date with the digital evolution. 
The following study aims to identify, among other parameters, challenges for actual and underdeveloped skills (hard, technical and soft), that participants of the educational process encountered through Final Qualification Assessment in programs of European and Oriental Languages in Eastern Europe and Asia.

\section{Methods}

\section{Final Qualification Assessment as an Educational Activity: Profiling}

Qualification assessment for Foreign Languages major programs is a mandatory, rigorous procedure that involves different stages of foreign language acquisition skills assessment (oral and written exams, final project viva, internal and external review).

The generic form of summative state qualification of students in countries of Europe and Asia is defined by the state standards of education and is reflected in the curricula of the Free Economic Zone. Usually state qualification has two forms, combined or separate:

1) State exam;

2) Defense (viva) of qualification (bachelor's or master's) paper.

State standards of education in countries of Europe and Asia typically provide for the existence and observance of rules and requirements for the procedure of Final Qualification Assessment (Law 2019; CCS 2015). Moreover, the defense of the qualification work contains propaedeutic procedures designed to obtain the basis for admission of students to the defense.

The qualification assessment regimen was adapted to digital format as a framework (a legal procedure that results in the degree confirmation of a student), the string of consecutive activities according to the legal procedure described in the profile above, the "ritual" scenario (and experience for the student that is emotionally uplifting and somber in nature, connects with the traditions of the university culture of Europe).

In the situation of the COVID-19 pandemic lockdown all elements of the Final Qualification Assessment at Borys Grinchenko Kyiv University for European and Oriental Languages programs have been relegated to the digital, remote or blended format with the use of ICT tools. This case is estimated in this study as a comprehensive best practice to suggest for implementation in higher educational institutions of Europe and Asia.

The following Qualification Assessment activities for European and Oriental languages programs have been transferred to digital remote mode:

- State exam conduct (introduction, oral answers, grading, discussion, results)

- State Exam card selection

- State Exam assessment

- State Exam results declaration and appeal

- Bachelor's project submission

- Bachelor's project review

- Bachelor's project viva/defense

- Bachelor's project assessment

- Bachelor's project results declaration and appeal.

The framework transformation of Final Qualification Assessment enticed the elaboration of adequate and equivalent digital formats and digital communicative settings, substituting each type of activity in the procedure regiment on each level of the Final Qualification Assessment framework:

1) Pre-assessment regimen;

2) Assessment proper regimen;

3) Post-assessment regimen.

A digital remote analogous activity was devised for each Qualification Assessment element. A selection of ICT tools was arranged and utilized to accommodate each Qualification Assessment activity for Oriental and European languages programs accordingly (Figure 1): 


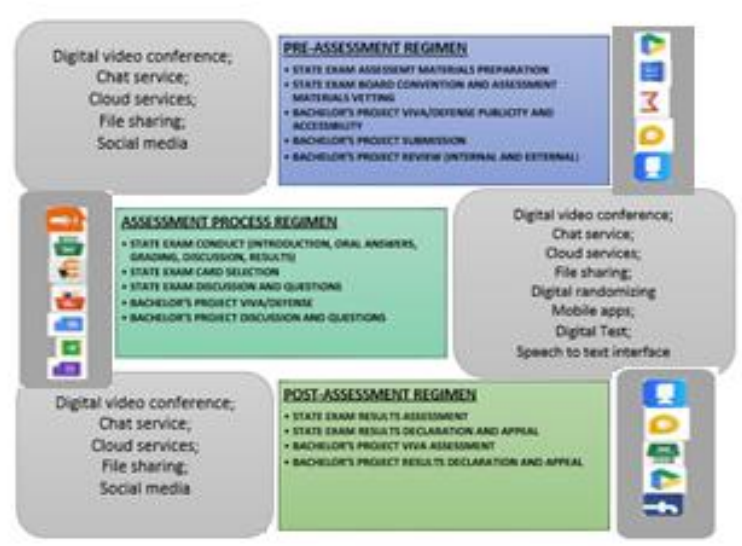

Figure 1. Qualification Assessment activities for foreign languages programs transfer to digital remote format

\section{Survey sample and design}

Informed by the Final Qualification Assessment activity profile, a survey was conducted among the participants of the Final Qualification Assessment at Borys Grinchenko Kyiv University (Kyiv, Ukraine) Foreign European and Oriental languages programs (Spanish, French, Italian, English, Mandarin Chinese, Japanese major) and International Business School (Hyderabad, India) Foreign languages programs. The survey aim was to comprehensively assess the efficiency of qualification assessment transfer into digital format via various ICT tools employed, to identify best practices and challenges in the corresponding skills formation for representatives of European and Oriental languages programs. The survey was conducted over the span of late June-early July of 2020, after the wrap up of all academic year Qualification Assessment procedures in the digital format both in Ukraine (Makhachashvili, Semenist, Bakhtina 2020) and in India.

The survey comprised of 12 questions total (multiple choice and scoring), divided into such categories:

1. Questions on overall experiences of Final Qualification Assessment participants in all procedures, conducted via ICT tools;

2. Questions on digital literacy skills, required of Final Qualification Assessment participants;
3. Questions on soft skills, required of Final Qualification Assessment participants;

4. Questions, aimed to conduct Efficiency Ranking (Dos Reis 2015; Makhachashvili, Semenist, Bakhtina 2020) of most widely used Final Qualification Assessment ICT tools.

The following groups of participants of the digital Final Qualification Assessment were respondents of the survey overall both in Ukraine and India:

- Students of senior year of bachelor's program;

- Assessment board members;

- Faculty members (who took part in digital qualification assessment preparation and conduct);

- Bachelor project referees and supervisors.

For the purposes of this paper we singled out student respondents, as primary subjects of Final Qualification Assessment digitized procedures.

A total of 45 students of Foreign European and Oriental languages programs (Spanish, French, Italian, English, Mandarin Chinese, Japanese major) at Borys Grinchenko Kyiv University, Ukraine, and 64 students of Foreign languages programs at International Business School (Hyderabad, India) were respondents of the survey. The sample sized for the analyzed cases of Final Qualification Assessment were determined by all senior year (Bachelor's level) students of European and Oriental Languages Programs in the sampled universities who underwent Qualification Assessment in the spring semester of 2020.

Respondents of all groups spanned the foreign language Bachelor's programs in proportional distribution measures:

- Spanish major program- 32,8\%

- Japanese major program- 19\%

- Mandarin Chinese major program - 22,4\%

- French major program - 15,5\%

- Italian major program- $15,5 \%$

- English major program - 38,6\%

- German major program - $2 \%$.

The choice of respondent groups corresponded to the variation or similarity of tasks, performed throughout Final Qualification Assessment by representatives of European and Oriental languages programs and, subsequently, the 
variation and similarity of ICT tools used in countries of Europe and Asia.

\section{Data Analysis and Results}

The overall digital qualification assessment experience on the scale of 1 to 5 was defined as mostly agreeable (4) by $50 \%$ of respondents, most agreeable (5) by $29 \%$ of respondents and less agreeable (3) by $17 \%$ of respondents of Borys Grinchenko Kyiv University, Ukraine. It's worth noting that the digital activities got overall rankings of 5-4 from respondents of European languages programs and 4-2 from respondents of Oriental languages programs.

Respondents from IBS (India) evaluate digital qualification assessment experience predominantly as less agreeable (3) - 48,5\% and mostly agreeable (4) $-25,8 \%$.

The respondents from Ukraine and India identified all the ICT digital tools that they have to employ the most in digital qualification assessment process (Figure 2). The highest scoring ICT tools by respondents of both European and Oriental language programs at Borys Grinchenko Kyiv University, Ukraine were:

- e-mail (93\% of respondents),

- $\quad$ Google services - combined (76\% of respondents),

- $\quad$ videoconferencing services (84\% of respondents),

- $\quad$ social media platforms (77\% of respondents),

- $\quad$ automated testing systems and learning management systems (31\% of respondents).

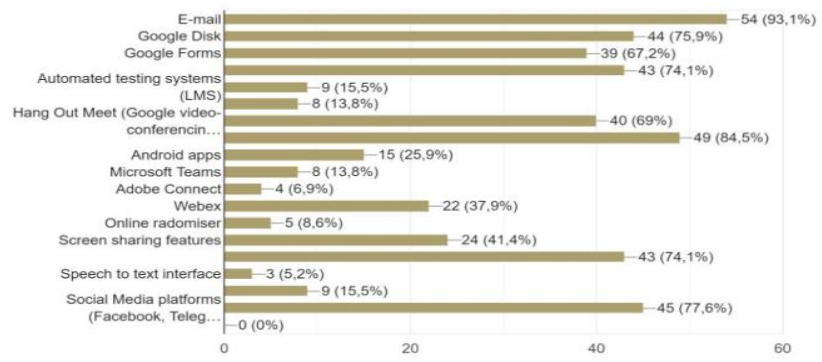

Figure 2. ICT tools identification through the digital qualification assessment (Borys Grinchenko Kyiv University, Ukraine)
In comparison, the highest scoring ICT tools by respondents of both foreign language programs at International Business School, India (Figure 3) were:

- $\quad$ e-mail (80\% of respondents)

- $\quad$ Google forms (76,9\% of respondents)

- Videoconferencing services (56\% of respondents)

- $\quad$ social media platforms $(46,2 \%$ of respondents),

- $\quad$ Microsoft Office Tools (46,2 of respondents).

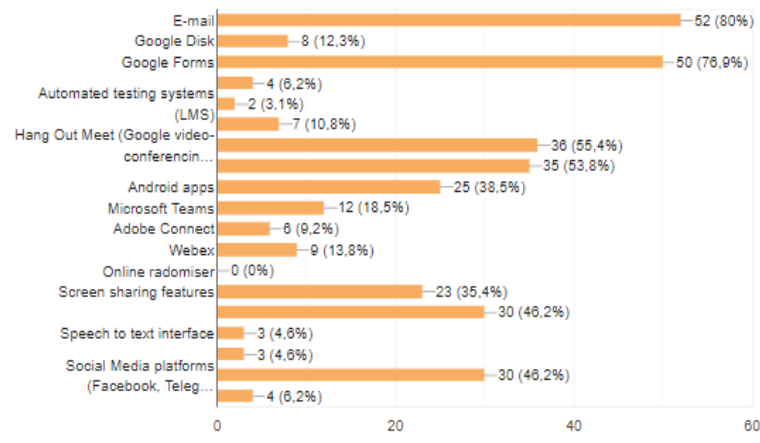

Figure 3. ICT tools identification through the digital qualification assessment (IBS, India)

The ranking 1-5 of the ICT tools employed through digital qualification assessment process yields following tools getting the highest scoring (5) among all ICT tools identified and used by respondents in Ukraine: email services; google forms; video conferencing services; screen sharing services; Microsoft Office tool-kit and various social media platforms. Respondents from India gave the following ICT tools the highest scoring (5): e-mail services; Android Apps; Microsoft Office tool-kit; social media platforms (Table 1). 
Table 1. Comparative scoring of highest ranking ICT tools for Final Qualification Assessment for respondents from Borys Grinchenko Kyiv University (Ukraine) and International Business School (India)

\begin{tabular}{|c|c|c|c|c|}
\hline ICT tools ranking 5 & BGKU (Ukraine) & Score & IBS (India) & Score \\
\hline E-mail services & + & $40 \%$ & + & $42 \%$ \\
\hline Google forms & + & $38 \%$ & + & $19 \%$ \\
\hline $\begin{array}{l}\text { Videoconferencing } \\
\text { services }\end{array}$ & + & $43 \%$ & - & - \\
\hline $\begin{array}{l}\text { Screen } \\
\text { services }\end{array}$ & + & $21 \%$ & - & - \\
\hline $\begin{array}{l}\text { Microsoft } \quad \text { Office } \\
\text { tool-kit }\end{array}$ & + & $47 \%$ & + & $31 \%$ \\
\hline $\begin{array}{l}\text { Social media } \\
\text { platforms }\end{array}$ & + & $46 \%$ & + & $32 \%$ \\
\hline Android Apps & - & - & + & 14 \\
\hline
\end{tabular}

Respondents from both Ukraine and India identified the following most prominent activities across all ICT tools used throughout the digital qualification assessment process (Figure 4):

- $\quad$ Communication (synchronous)

- Communication (asynchronous)

- Collaboration

- Information/file sharing

- $\quad$ Summative assessment

- Formative assessment

- Peer review

- Presentation

- $\quad$ Speech quality assessment

- $\quad$ Brainstorming
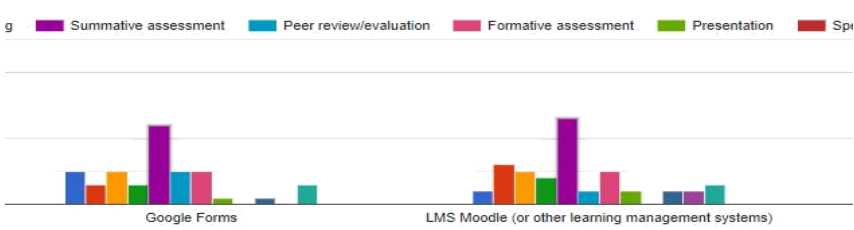

Figure 4. Activities per ICT tools used throughout the digital qualification assessment. Sample evaluation card

Information sharing and presentation are considered prominent for such types of tools as e-mail, Google Suite services, Microsoft Office Toolkit.

Both synchronous and asynchronous communication and collaboration is distributed proportionally among email services, learning management systems and various video conference services.

The tools that feature summative assessment as a prominent activity are Google forms and LMS Moodle.
Formative assessment as a type of activity features but does not dominate evaluation of ICT tools used qualification assessment process. The following technical and user requirements, most prominent for ICT/digital tools employed throughout the digital qualification assessment process were identified (Figure 5):

- $\quad$ Bandwidth

- $\quad$ Specialized software

- Specialized hardware (webcam, mic, PC type etc.)

- Intuitive interface

- $\quad$ Advanced digital literacy

- Intermediate digital literacy

- $\quad$ Elementary digital literacy

- $\quad$ Customized training before use

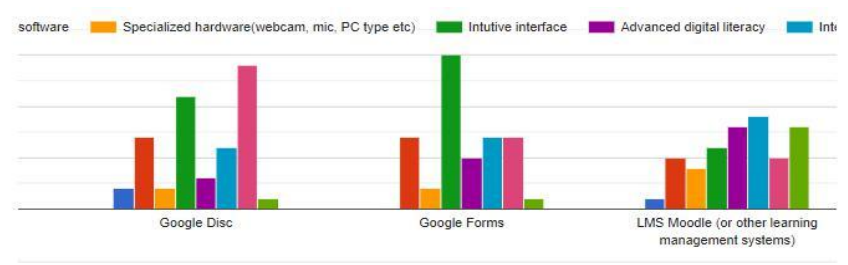

Figure 5. Technical and user requirements, for ICT tools digital qualification assessment process. Sample evaluation card

Intuitive interface is a technical requirement to future the most across the board of ICT tools that have been analyzed by respondents from Borys Grinchenko Kyiv University, Ukraine of Borys Grinchenko Kyiv University, Ukraine. It is considered a leading technical requirement for such ICT tools as email, Google Suite services, video conferencing services and social Media platforms. 
Specialized software is a technical requirement to future the most across all ICT tools that have been analyzed by respondents from International Business School, India. It is identified as a leading technical requirement for such ICT tools as email, Google Suite services, video conferencing services, automated testing platforms, Microsoft Office Toolkit. In and of itself such discrepancy is indicative of various levels of digital literacy in academia in different countries, as is corroborated by data presented further (Fig. 5-7).

Respondents of the European languages program of Borys Grinchenko Kyiv University, Ukraine have assessed the prominent ICT tools requirements (Figure 6) being Intuitive interface $(28,8 \%)$, elementary digital literacy $(26,9)$ and specialized software $(17,3 \%)$.

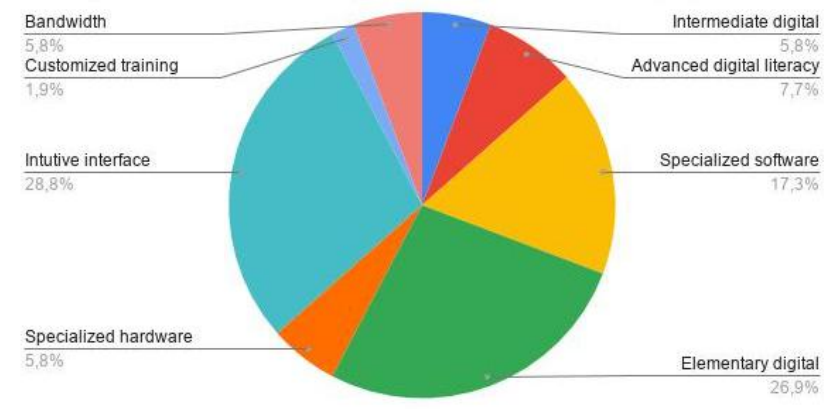

Figure 6. Technical and user requirements, for ICT tools digital qualification assessment process for European languages program of Borys

Grinchenko Kyiv University, Ukraine

Respondents of the Oriental languages program of Borys Grinchenko Kyiv University, Ukraine have assessed the prominent ICT tools requirements (Figure 7) being Intuitive interface $(31,8 \%)$, elementary digital literacy $(31,8)$ and bandwidth and advanced digital literacy $(9,1)$.

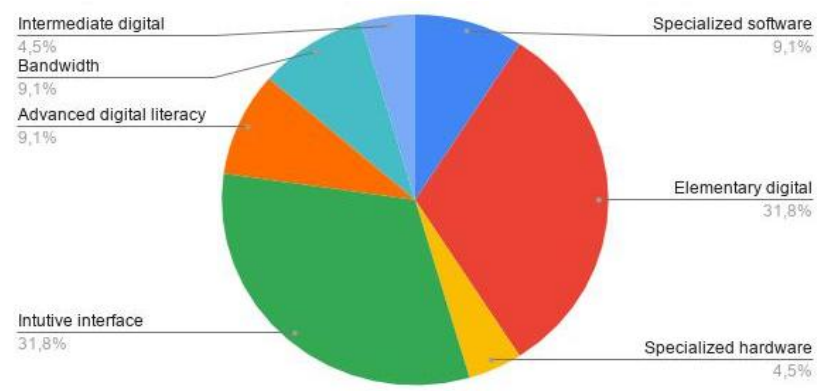

Figure 7. Technical and user requirements, for

ICT tools digital qualification assessment process for Oriental languages program of Borys Grinchenko Kyiv University, Ukraine
Respondents of the European languages program of International Business School, India have identified the prominent ICT tools requirements (Figure 8) being Specialized software $(30,0 \%)$, Bandwidth $(25,0 \%)$ and advanced digital literacy, specialized hardware and customized training $(10,0 \%)$.

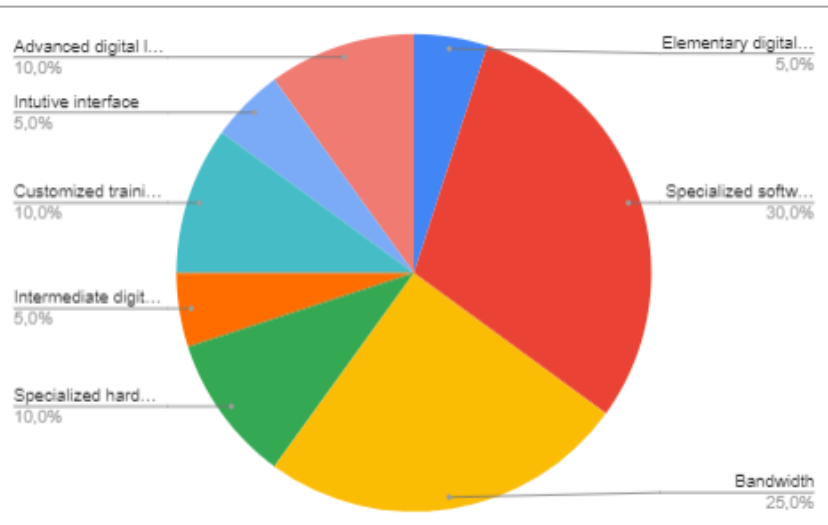

Figure 8. Technical and user requirements, for ICT tools digital qualification assessment process for European languages program of International Business School, India

According to skills of the $21^{\text {st }}$ century frameworks, various levels of digital literacy have been identified in the survey. Digital literacy is understood primarily as the ability to use information and communication technologies to find, evaluate, create, and communicate information, requiring both cognitive and technical skills (ALA, 2020; DQ Report, 2019).

Advanced digital literacy as the requirement for qualification assessment ICT tools efficiency is attributed overall by students of foreign languages programs to such ICT instruments as learning management systems, Android apps, screen sharing services, Microsoft Office toolkit and social media platforms.

Intermediate digital literacy is required predominantly for such instruments as Google Suite services, Microsoft Office Toolkit, screen sharing interface, videoconferencing services, online randomizer, automated testing system, learning management system.

Elementary digital literacy level is assessed as dominant for such tools as email, google disc, 
video conferencing, cloud based presentation tools, speech to text interfaces and social media platforms.

The comparative distribution of various levels of digital literacy requirements for ICT tools used for

Table 2. Comparative distribution of various levels of digital literacy requirements for ICT tools used for Final Qualification Assessment procedures by respondents from Ukraine and India

\begin{tabular}{|c|c|c|}
\hline \multirow[t]{2}{*}{ Digital literacy level } & \multicolumn{2}{|c|}{ ICT tools for Final Qualification Assessment } \\
\hline & BGKU, Ukraine & IBS, India \\
\hline Advanced digital literacy & $\begin{array}{l}\text { Learning management systems, } \\
\text { Microsoft Office toolkit, social } \\
\text { media platforms }\end{array}$ & $\begin{array}{l}\text { Google Suite services, learning } \\
\text { management systems, Android } \\
\text { Apps, screen sharing services }\end{array}$ \\
\hline Intermediate digital literacy & $\begin{array}{l}\text { Microsoft Office Toolkit, screen } \\
\text { sharing interface, } \\
\text { randomizer, automated testing } \\
\text { system, learning management } \\
\text { system }\end{array}$ & $\begin{array}{l}\text { Videoconferencing services, } \\
\text { Google Suite services, email, } \\
\text { speech to text interface }\end{array}$ \\
\hline Elementary digital literacy & $\begin{array}{l}\text { email, google disc, video } \\
\text { conferencing, speech to text } \\
\text { interfaces }\end{array}$ & Cloud based presentation tools \\
\hline
\end{tabular}

Across various ICT tools for the digital qualification assessment process the following skills and competences most widely implemented and practiced, drawn from various relevant $21^{\text {st }}$ century skills frameworks have been identified:

- Communication;

- Collaboration

- $\quad$ Team work

- Digital literacy

- $\quad$ Emotional intellect

- Interdisciplinary skills

- $\quad$ Critical thinking

- $\quad$ Leadership

- $\quad$ Flexibility and Adaptability

- Decision making

- $\quad$ Learning and Innovation skills

Different priorities in soft skills are identified for participants of digital Qualification assessment of the European languages program (Figure 9) and Oriental languages program (Figure 10) of Borys Grinchenko Kyiv University, and Foreign Languages program of International Business School, India (Figure 11):
Final Qualification Assessment procedures by respondents of Borys Grinchenko Kyiv University, Ukraine and International Business School, India is presented as follows (Table 2): 


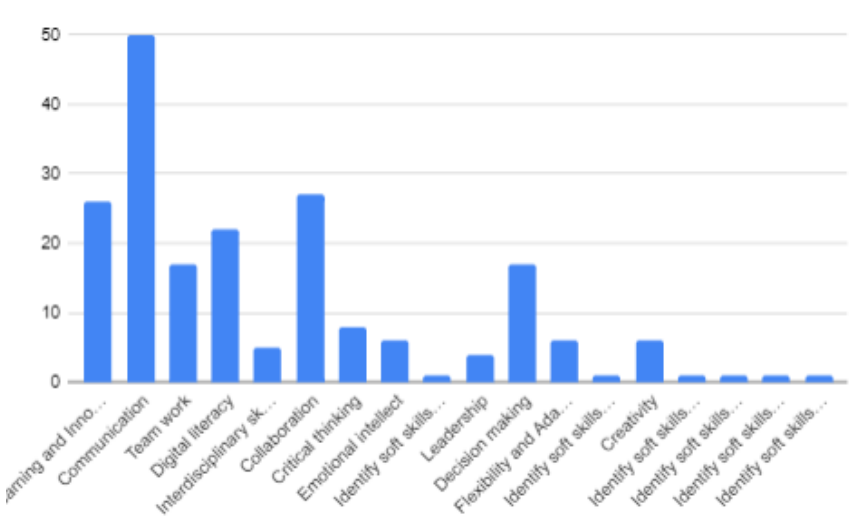

Figure 11. Soft skills for ICT/digital tools in digital qualification assessment process for Foreign languages program at International Business School, India

Table 3. Comparative score of top soft skills, identified as necessary for successful Final Qualification Assessment respondents form Ukraine and India

\begin{tabular}{|c|c|c|c|c|}
\hline Soft skills & BGKU (Ukraine) & Score & IBS (India) & Score \\
\hline Communication & + & $95 \%$ & + & $83,3 \%$ \\
\hline Collaboration & + & $81 \%$ & + & $44 \%$ \\
\hline Team work & + & $78 \%$ & + & $17 \%$ \\
\hline Decision making & + & $12 \%$ & + & $16 \%$ \\
\hline $\begin{array}{l}\text { Flexibility } \\
\text { adaptability }\end{array}$ & + & $9 \%$ & - & (less than $10 \%$ ) \\
\hline Digital literacy & - & less than $10 \%$ ) & + & $31 \%$ \\
\hline $\begin{array}{l}\text { Learning and } \\
\text { Innovation }\end{array}$ & - & less than $10 \%$ ) & + & $42 \%$ \\
\hline
\end{tabular}

As is apparent form the data, the range of soft skills, identified as prominent by respondents from Ukraine and India is different. Respondents from European and Oriental languages programs of Borys Grinchenko Kyiv University, Ukraine scored Communication (95\%), Collaboration $(81 \%)$ and Team work $(78 \%)$ as overwhelmingly significant. Top soft skills identified by respondents from Foreign languages program of International Business School, India, are Communication $(83,3 \%)$, Collaboration (44\%) and Learning/innovation (42\%).

Communication and collaboration rank as a type of skills most widely applied for the use of such instruments as email, Google services, video conferencing services and social Media platforms. Team work ranks second most prominent skill employed through the use of Google disk, learning management systems and video conferencing services. Learning and Innovation skills feature as priority relevant in the use of such ICT tools as a learning management system (ranking second after interdisciplinary skills), automated Testing System (offline, online and cloud based), Android apps and Microsoft Office tools.
Top soft skills scores, identified as necessary for successful Final Qualification Assessment respondents form Ukraine and India, are distributed in the following way (Table 3): 
notice to carry out the full spectrum of necessary activities for Final Qualification Assessment.

The comprehensive transference process of the Final Qualification Assessment procedure for European and Oriental languages programs in Ukraine and India from face-to-face into alldigital format was accompanied by the following identified common challenges across various socio-cultural contexts in Ukraine and India:

- Normative documentation digital format adaptation;

- The need for digital literacy training for participants of the Final Qualification Assessment process for all stages of the procedure;

- Digital divide in accessibility of computer and Web technologies, necessary for all stages of Final Qualification Assessment;

- Soft skills challenges.

Various levels of digital literacy have been identified in the survey in sampled universities of Europe (Ukraine) and Asia (India). Across the board, implementation of Final Qualification Assessment via various ICT tools requires of participants of educational process intermediate digital literacy. There's a significant observed discrepancy in digital literacy and ICT competence requirements between Final Qualification Assessment participants of European and Oriental languages programs of Borys Grinchenko Kyiv University, Ukraine (elementary to intermediate digital literacy required) and International Business School, India (intermediate to advanced digital literacy required).

\section{Limitations and Future Studies}

The survey results were limited to the number of respondents, who underwent Final Qualification procedures in European and Oriental Languages programs in the timespan of spring semester, 2020, both in Ukraine and India. The benchmarking data has been subsequently collected in the winter semester of 2020 across the proportional sample of respondents to identify the progress in soft skills development and digital skills evolution after a full year of COVID-19 online education measures for European and Oriental Languages programs. The survey results will be furthered and elaborated in assessment of soft and digital skills adaptability for separate groups of Final Qualification Assessment participants (students of foreign languages programs in countries of Europe and Asia, Assessment board members, staff members, reviewers) according to roles and tasks performed, as well as according to age and entry digital literacy level in universities of Europe and Asia.

\section{Conclusion}

Communication, collaboration and team work are evaluated as crucial interdisciplinary skills in various combinations within the scenario of digital Final Qualification Assessment. This results corroborate the cross-domain correspondence between communicative competence and ICT competence components, adapted for Liberal Arts. Namely. The following digital communicative components prove indispensable for all participants of Final Qualification Assessment in digital format: participation in group ICT initiatives, creating elearning tasks, system using of ICT, presentation to the community the results of one's own research activities through the use of ICT.

\section{Acknowledgement}

The research methodology leading to these results was elaborated within the framework of the IRNet project, funding from the People Program (Marie Curie Actions) of the European Union's Seventh Framework Program FP7/2007-2013/ under REA grant agreement No: PIRSES-GA-2013- 612536. Empirical findings and survey procedures have been conducted under the auspices of Integrated Research framework of Romance Languages and Typology Chair of Borys Grinchenko Kyiv University European languages and literatures development in cross-communication context (0116 U 006607) and Integrated Research framework of Oriental Languages and Translation Chair of Borys Grinchenko Kyiv University Oriental Studies development in the framework of Higher Education Internationalization (0116U007073).

\section{References}

[1] Abbott S. (2013). The Glossary of Education Reform. Retrieved from: 
http://edglossary.org/hidden-curriculum (accessed July 2020).

[2] American Library Association (2020). Digital Literacy. Retrieved from: https://literacy.ala.org/digital-literacy (accessed July 2020).

[3] Centre for Civil Society (2015). Regulatory Structure of Higher Education in India. Retrieved from: https://ccs.in/sites/default/files/research/res earch-regulatory-structure-of-highereducation-in-india.pdf (accessed November 2020).

[4] Davies A., Fidler D. et al (2011). Future Work Skills 2020. Institute for the Future for University of Phoenix Research Institute. Retrieved from: https://www.iftf.org/uploads/media/SR1382A_UPRI_future_work_skills_sm.pdf (accessed October 2020).

[5] Dos Reis A. (2015). To Be a (Blended) Teacher in the 21st Century - Some Reflections. International Journal of Research in E-learning, 1(1), 11-24.

[6] Dos Reis A. (2017). Digital Storytelling and Technologies. Electronic Scientific Professional Journal "Open Educational E-Environment of Modern University”, 3, 106-112.

[7] DQ Global Standards Report (2019). World's first global standard for digital literacy, skills and readiness launched by the Coalition for Digital Intelligence. Retrieved from: https://www.dqinstitute.org/ (accessed July 2020).

[8] European Commission (2020). Digital Competence 2020. Retrieved from: https://ec.europa.eu/jrc/en/digcomp/digital -competence-framework. (accessed October 2020).

[9] European Commission (2020). European E-Competence Framework Guideline. Retrieved from: https://www.ecompetences.eu/ (accessed July 2020).

[10] Hymes, Dell H. (1972). Communicative competence. In Pride, J.B., \& J. Holmes, J.
(Eds.) Sociolinguistics: selected readings. (pp. 269-293). Harmondsworth: Penguin.

[11] Law of Ukraine (2019). On Higher Education. Retrieved from: https://zakon.rada.gov.ua/laws/show/155618\#Text (accessed July 2020).

[12] Makhachashvili, R., Semenist, I., \& Bakhtina, A. (2020). Digital Skills Development and ICT Tools for Final Qualification Assessment: Survey Study for Students and Staff of European and Oriental Philology Programs. Electronic Scientific Professional Journal "OPEN EDUCATIONAL E-ENVIRONMENT OF MODERN UNIVERSITY", (9), 54-68. https://doi.org/10.28925/24140325.2020.9.5

[13] Makhachashvili, R., Semenist, I., \& Bakhtina, A. (2020). ICT Tools and Practices for Final Qualification Assessment in the Framework of COVID19 Lockdown. Innovative Educational Technologies, Tools and Methods for Elearning Monograph. University of Silesia in Katowice, Poland, Katowice. Pp. 183194.

[14] Morze N., Makhachashvili R., SmyrnovaTrybulska E. (2016). Communication in education: ICT tools assessment. Proceedings from DIVAI, (pp. 351-354). Sturovo: University of Nitra.

[15] Morze N., Makhachashvili R., SmyrnovaTrybulska E. (2016). Research in Education: Survey Study. Information and Communication Technologies in Education, 3, 114-123.

[16] Taleb, N. (2010). The Black Swan: The Impact of the Highly Improbable (2nd ed.). London: Penguin. ISBN 978-0-141034591.

[17] UNESCO (2018). ICT Competency Framework for Teachers. Retrieved from: https://unesdoc.unesco.org/ark:/48223/pf0 000265721 (accessed July 2020).

[18] World Economic Forum (2020). The Future of Jobs Report. Retrieved from: http://www3.weforum.org/docs/WEF_Future of_Jobs_2020.pdf (accessed October 2020). 


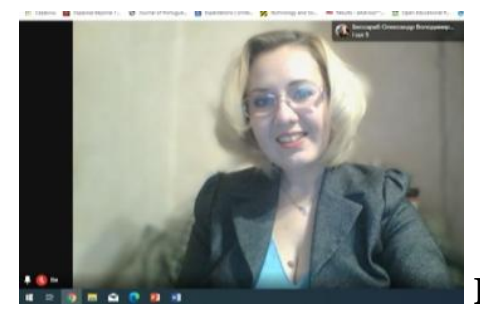

\section{RuSUdan MAKHACHASHVILI}

Doctor Habilitated, English and Spanish major, Head of Romance Languages and Typology Department of Borys Grinchenko Kiyv University, Ukraine. Editor in Chief of the Journal "Synopsis: Text. Context. Media". Main academic interests: digital education, digital humanities, digital literacy development, cognitive and communicative linguistics, digital linguistics and lexicography. European Commission Horizon 2020 Grant Evaluation Expert. Exemplary published works: Linguophilosophic Parameters of English Innovations in Technosphere (UK 2015), Models and Digital Diagnostics Tools for the Innovative Polylingual Logosphere of Computer Being Dynamics (Peter Lang, Berlin, 2020), ICT Tools and Practices for Final Qualification Assessment in the Framework of COVID-19 Lockdown (Poland, 2020).

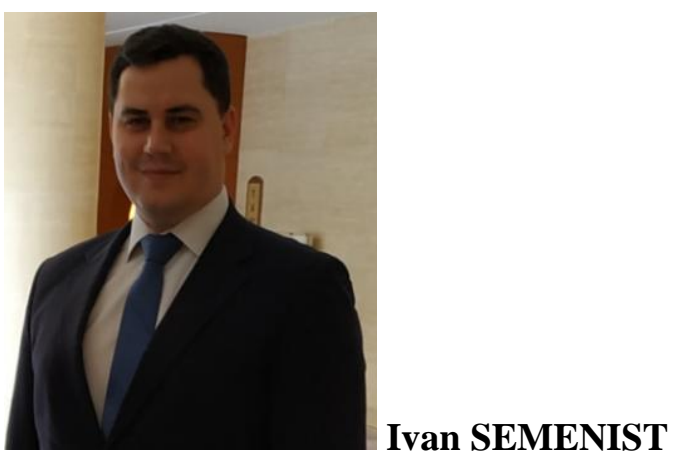

$\mathrm{PhD}$, Orientologist, Head of Oriental Languages and Translation Department, Head of Ukranian National Association of Teachers of Chinese, Borys Grinchenko Kiyv University, Ukraine. Editor in Chief of Ukrainian Journal of Sinology Studies. Main academic interests: oriental studies, oriental languages, cultural and linguistic-literary ties of Ukraine with the countries of the East, relations of Ukraine with the countries of the East. Exemplary published works: Modern Chinese Society - New Perspectives: New research between China and Ukraine scientists (Social Sciences Academic Press, China 2017), Japan's new role in the world: the discussion of early 1990's (Ukraine 2016), ICT Tools and Practices for Final Qualification Assessment in the Framework of COVID-19 Lockdown (Poland, 2020).

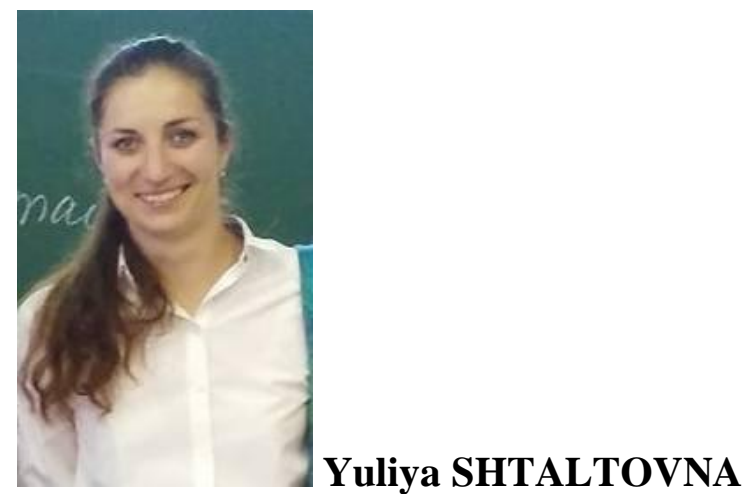

$\mathrm{PhD}$, English and Ukrainian Major. Associate Professor at XU Exponential University of Applied Sciences, Berlin, Germany. Main academic interests: Democratization of English and of Higher Education, Business Communication, Democratization of English and European languages, internationalization of education with a focus on Intercultural Communication and Sociolinguistics, Methodology and Didactics of Business and Academic English, Applied Soft Skills Development. Exemplary published works: The pursuit of democratization in education - knowing where to go. Concept analysis for the correct use of the term "Democratization of Education" (Ukraine 2017), How to make it REAL? Real-world cases for Business and Professional English Teaching (Germany, 2020). 


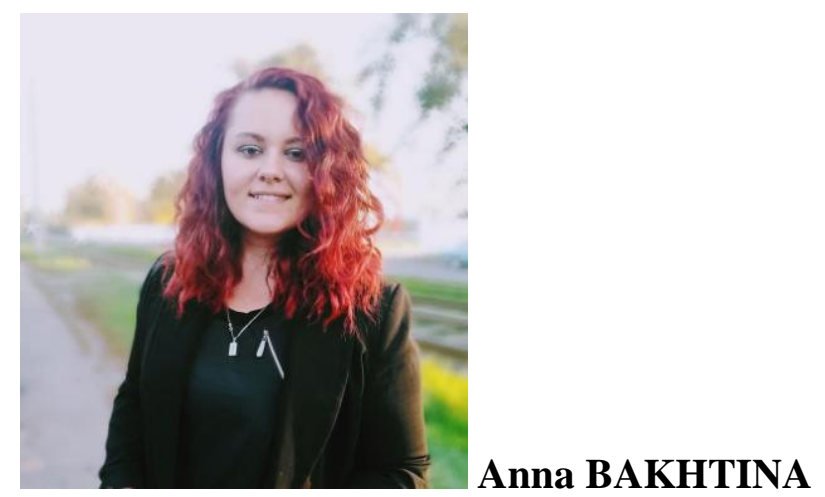

$\mathrm{PhD}$ student, Spanish and Ukrainian Major. Assistant Professor of Romance Languages and Typology Department of Borys Grinchenko Kiyv University, Ukraine. Expert of the National Education Quality Assurance Agency. Main academic interests: digital linguistics, corpus linguistics, e-learning, artificial intelligence and deep learning, analytical philosophy, digital iconicity. Exemplary published works: Technology of poetry presentation via emojimaker platform ICT tools: pedagogical function of graphic mimesis (Ukraine 2020); Empirical method of emoji polylaterality analysis (Ukraine, 2020) Digital Skills development and ICT Tools for final qualification assessment: survey study for students and Staff of European and Oriental philology programs (Ukraine 2020). 